7. Reprod. Fert. (1974) 39, 53-64

\title{
FOLLICULAR DEVELOPMENT IN THE INFANT HUMAN OVARY
}

\author{
SUE LINTERN-MOORE,* HANNAH PETERS, G. P. M. MOORE* \\ AND M. FABER \\ The Finsen Laboratory, The Finsen Institute, Copenhagen, Denmark
}

(Received 12th November 1973)

\begin{abstract}
Summary. The morphology and growth pattern of human ovarian follicles has been studied between birth and 9 years of age. Follicles have been classified according to their morphology, diameter, the diameter of the oocyte and the number of granulosa cells in the widest cross-section. Nine major classes of follicle were recognized. The smallest, Class B follicles, contained a non-growing oocyte and were surrounded by a single layer of flattened granulosa cells. The largest, Class F follicles, which were up to $6 \mathrm{~mm}$ in diameter, contained an oocyte which had completed growth $(80 \mu \mathrm{m})$ and a large fluid-filled antrum. The range of follicles and the pattern of oocyte growth in relation to follicle growth found in the ovary was independent of age during childhood.

Follicular growth and atresia are discussed in the light of current concepts of gonadal and pituitary function during infancy and childhood.
\end{abstract}

\section{INTRODUCTION}

The morphological changes which occur within the human ovary during infancy and childhood have been described in detail. Maturation of the ovary is indicated by increases in ovarian weight and size, flattening of the surface epithelium, development of the tunica albuginea ovarii, changes in the orientation and quantity of connective tissue in the stroma and increased vascularization (Stevens, 1903; Shaw, 1925; Simkins, 1932; Forbes, 1942; Delson, Lubin, \& Reynolds, 1949; Sauramo, 1954; Boyd \& Hamilton, 1955; Curtis, 1962; Merrill, 1963; Potter, 1963; Mossman, Koering \& Ferry, 1964; Van Wagenen \& Simpson, 1965; Valdes-Dapena, 1967; Mossman \& Duke, 1973).

The most striking characteristic of the infant ovary is the presence of follicles in all stages of growth and atresia. The occurrence of antral follicles (both microscopic and macroscopic) from 7 months after conception onwards has been reported on numerous occasions. Spivak (1934) reviewed accounts dating from the early 18th century of 'cystic follicles' in newborn ovaries. More recently, this subject has been dealt with by Govan \& Mukherjee (1950), Polhemus (1953), Ober \& Bernstein (1955), Ahlvin \& Bauer (1957), Curtis (1962), Kraus \& Neubecker (1962), Winter (1962) and Merrill (1963).

\footnotetext{
* Present address: Department of Zoology, Australian National University, Canberra ACT, Australia.
} 
In the present study, the quantitative patterns of oocyte and follicular growth are investigated during the period of infancy. Using this information, a classification for the follicle types found in the infant ovary has been derived. The classification is intended to form a basis for studies of the dynamics of follicular growth in the human ovary.

\section{MATERIALS AND METHODS}

Ovaries were obtained at autopsy from infants and children ranging in age from birth to 9 years. The specimens were fixed in Bouin's solution, embedded in paraffin wax and sectioned at $7 \mu \mathrm{m}$. Sections were stained with either Harris haematoxylin and eosin or Heidenhain's Azan.

In order to determine the incidence and sizes of antral follicles in ovaries at different ages, an initial survey was made of sectioned material obtained from 400 subjects. From these, a group was selected consisting of nineteen

\section{EXPLANATION OF PLATE 1}

Fig. 1. Class A human oocytes (oo- -9 to $25 \mu \mathrm{m}$ diam.) in the transition stages of meiotic prophase. At birth, these were found either in the extreme outer cortex abutting the surface epithelium (s.e.) (Fig. 1a) or in the medullary region of the ovary (Fig. 1b). After 2 months of age, Class A follicles were less abundant. They were mainly found in medullary nests, surrounded by cells which resembled those of the rete ovarii and were encapsulated by a complete basement membrane. Age 3 days; $\times 910$.

FIG. 2. Class B (right) and B/C (left) oocyte nuclei which have entered the resting stage of diplotene. Class B follicles were surrounded by flattened granulosa cells with highly basophilic nuclei. Class B/G follicles had both flattened and cuboidal granulosa cells. In general, the flattened cells surrounded one side of the oocyte and cuboidal cells the other. Whether the cuboidal cells arise from the flattened granulosa cells or represent a different cell population is unknown. Oocytes of $\mathbf{B}$ follicles form the major portion of the oocyte population in the ovary at any time and constitute the resting pool from which future follicular growth will occur. They occurred in great abundance in the outer cortex at birth and thereafter appeared less commonly due not only to an increase in the size of the ovary but also to atresia (Baker, 1963). Age 5 years; $\times 910$.

Fig. 3. A Class $\mathbf{C}$ oocyte surrounded by a single complete layer of cuboidal granulosa cells and a complete basement membrane which separates the granulosa layer from the adjacent stroma. The stroma surrounding the follicle formed a halo of connective tissue fibres and fibroblast-like cells. No definitive theca was present. The oocyte had not commenced growth but the number of follicle cells had increased. Class $\mathrm{C}$ follicles were located deeper in the cortex than those of Classes $B$ and $B / C$ and were less frequently found than the latter. Age 7 years; $\times 910$.

FIG. 4. A Class $D_{1}$ follicle containing a growing oocyte surrounded by two to seven layers of granulosa cells. The zona pellucida is now present. Class $D_{1}$ follicles were located deeper in the cortex than those of any of the previous classes. Age 3 years; $\times 910$.

Fig. 5. A Class $D_{2}$ follicle. These follicles had a similar follicle and oocyte size range and location as $D_{1}$ but were characterized by a granulosa cell layer containing fluid filled spaces and Call-Exner (c.e.) vacuoles. Age 8 years; $\times 910$.

Fig. 6. A Class $\mathrm{E}$ follicle. These follicles occurred less frequently than any of the previous follicle classes and were characterized by a definitive crescent-shaped antrum. The oocyte had ceased growth in the majority of cases. The wide distribution of follicle sizes (Textfig. 5) in this class suggests that fluid accumulation may occur at any stage in follicular development after the formation of two or more layers of granulosa cells. The theca (th) may be well vascularized. Age 3 years; $\times 910$.

Fig. 7. A Glass $F$ follicle. These follicles lay deep in the medullary region of the ovary and represented the final stage of follicle growth in the infant ovary. They were characterized by the development of a large fluid-filled antrum and the oocyte, which had ceased growth, was embedded in a cumulus of granulosa cells. In some cases, the cells of the theca might be markedly hypertrophied, taking on a partly luteinized appearance. Vascularization of the theca was advanced. Part of an atretic Class F follicle (a) is seen to the lower left. Note the undifferentiated thecal-type interstitial gland cells. Age 8 years; $\times 146$. 

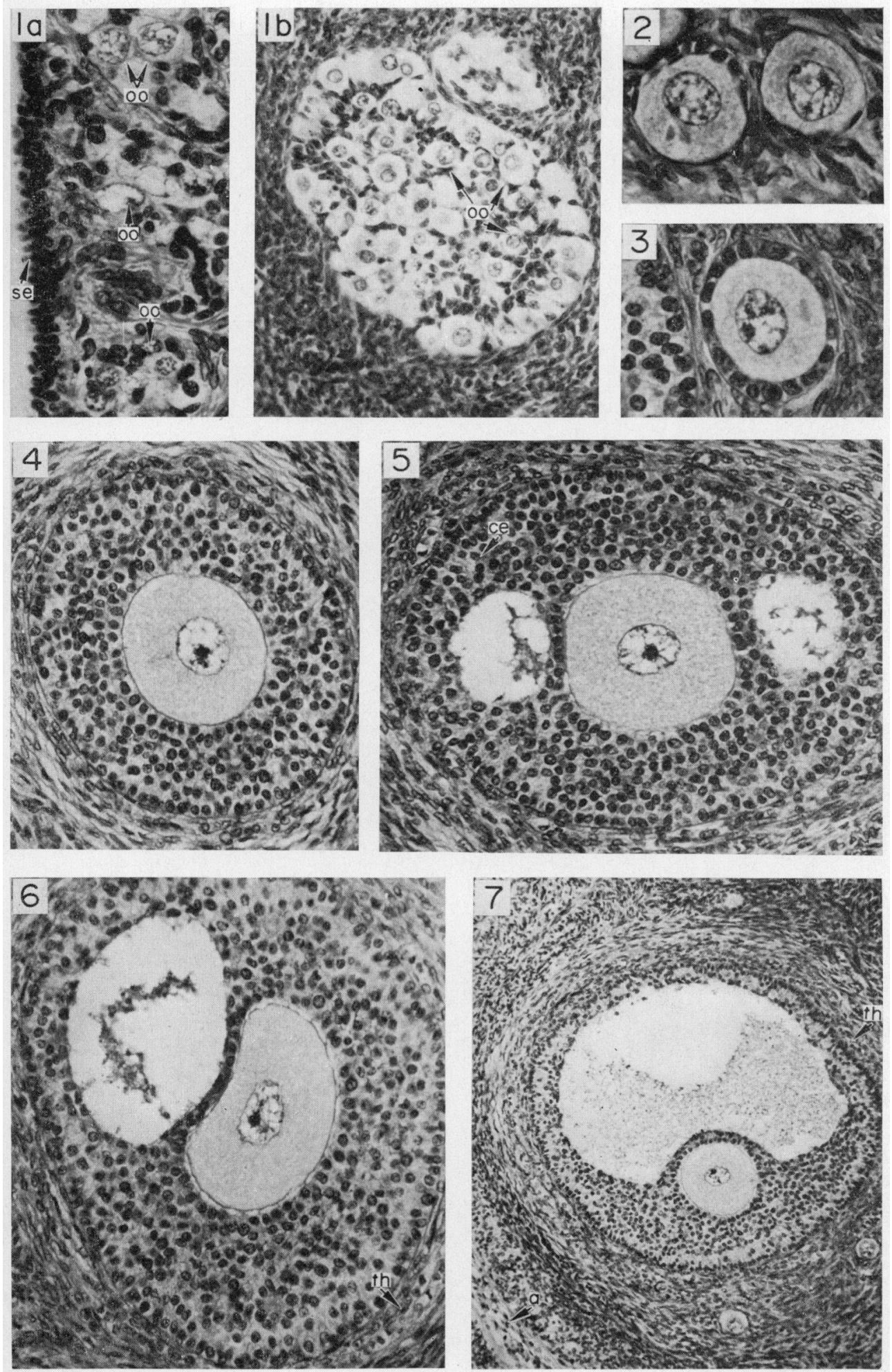
normal subjects ranging in age from birth to 9 years, who had died either from misadventure (eight cases) or acute disease (eleven cases) in which the period of illness was not longer than $48 \mathrm{hr}$ and its nature considered unlikely to affect the ovary. The follicle classification is based on measurements made on the ovaries from this group. Ovary sections were examined under a Zeiss projection microscope. Measurements were only made of those follicles which showed no apparent signs of atresia or post-mortem degeneration, i.e. the nuclei of the granulosa cells and oocytes showed no signs of pyknosis and macrophages were absent (see Baker, 1963). The diameters of the follicle, oocyte and oocyte nucleus were then obtained using the method described by Mandl \& Zuckerman (1952) and the number of granulosa cells were counted in the widest cross-section of the follicle. Approximately twenty representatives of each follicle class were measured in each of the nineteen ovaries. This was not possible with the larger follicles which occurred much less frequently than the smaller ones and, in most cases, were atretic.

\section{RESULTS}

Incidence and size of antral follicles

The survey of 400 ovaries showed that the range of morphological types of

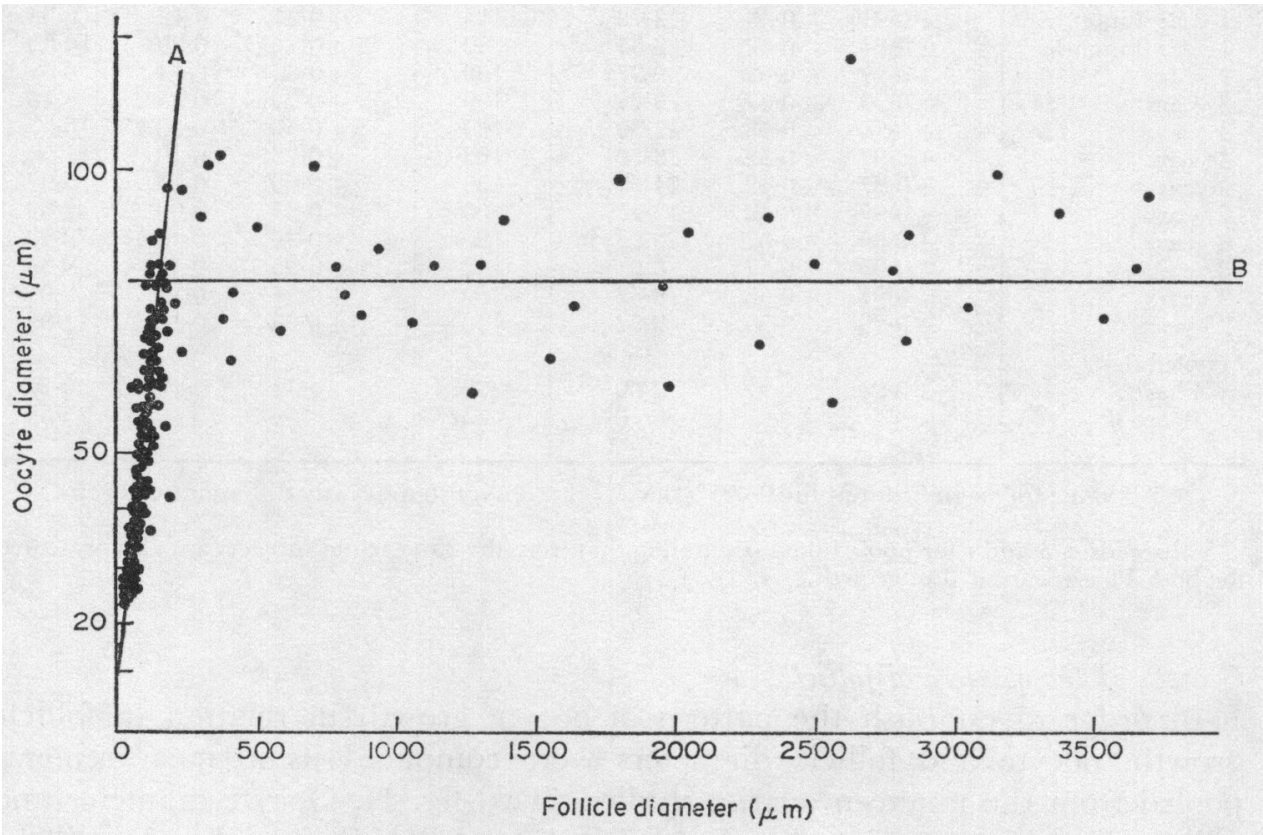

TeXT-FIG. 1. The relationship between oocyte diameter $(\mu \mathrm{m})$ and follicle diameter $(\mu \mathrm{m})$ in the infant human ovary. During Phase A of growth, these are positively and significantly correlated $(r=+0.91 ; P<0.001 ; y=0.57 \mathrm{x}+9.89$-for abbreviations, see Table 1). During Phase $B(y=0.001 x+80.70)$, the regression coefficient was not significantly different from zero. The point of intersection of the lines of best fit for both sets of parameters was highly sensitive to small variations in both the regression coefficients, $a$, and intercepts, $b$. The points which fell around the intersection of the two lines were excluded from the calculations (Mandl \& Zuckerman, 1952). 
follicles present in the ovary was similar regardless of the age of the subject. Antral follicles were present in $60 \%$ of the newborn ovaries. This frequency declined between 9 and 28 days of life to $30 \%$, but rose to $100 \%$ by the age of 1 year. Thereafter, antral follicles were always found in the ovary throughout infancy and childhood. The mean diameter of antral follicles ranged from $0.2 \mathrm{~mm}$ to $6 \mathrm{~mm}$ and was independent of age.

Table 1. Coefficients of straight line regression relationships $(\mathrm{y}=a \mathrm{x}+b)$ between oocyte diameter $(\mathrm{y})$ or oocyte nuclear diameter $(\mathrm{y})$ and follicle diameter $(\mathrm{x})$ and their corresponding correlation coefficients $(r)$ for Phase A of growth in twenty normal human female subjects aged between 3 days and 25 years

\begin{tabular}{|c|c|c|c|c|c|c|c|}
\hline Age & \multicolumn{3}{|c|}{$\begin{array}{c}\text { Oocyte diameterlfollicle diameter } \\
(\text { Phase } A)\end{array}$} & $\begin{array}{c}\text { No. } \\
\text { of pairs } \\
\text { of } \\
\text { measure- } \\
\text { ments }\end{array}$ & \multicolumn{3}{|c|}{$\begin{array}{c}\text { Oocyte nuclear diameter/follicle } \\
\text { diameter (Phase A) }\end{array}$} \\
\hline $\begin{array}{l}3 \text { days } \\
14 \text { days } \\
7 \text { weeks } \\
3 \text { months } \\
4 \text { months } \\
4 \frac{1}{2} \text { months } \\
11 \text { months } \\
1 \text { year } \\
1 \text { year } 4 \text { months } \\
1 \text { year } 9 \text { months } \\
2 \text { years } \\
2 \text { years } \\
3 \text { years } \\
4 \text { years } \\
5 \text { years } \\
7 \text { years } \\
8 \text { years } \\
8 \text { years } \\
9 \text { years } \\
25 \text { years }\end{array}$ & $\begin{array}{l}+0.90 \\
+0.88 \\
+0.89 \\
+0.93 \\
+0.80 \\
+0.94 \\
+0.94 \\
+0.98 \\
+0.91 \\
+0.84 \\
+0.97 \\
+0.99 \\
+0.96 \\
+0.97 \\
+0.87 \\
+0.97 \\
+0.95 \\
+0.95 \\
+0.97 \\
+0.99\end{array}$ & $\begin{array}{l}0.47 \\
0.64 \\
0.49 \\
0.66 \\
0.53 \\
0.58 \\
0.51 \\
0.44 \\
0.49 \\
0.52 \\
0.69 \\
0.57 \\
0.48 \\
0.52 \\
0.49 \\
0.48 \\
0.52 \\
0.52 \\
0.55 \\
0.55\end{array}$ & $\begin{array}{r}14 \cdot 22 \\
14 \cdot 85 \\
10 \cdot 42 \\
8 \cdot 36 \\
7 \cdot 09 \\
9 \cdot 16 \\
13 \cdot 21 \\
15 \cdot 11 \\
12 \cdot 78 \\
8 \cdot 84 \\
9 \cdot 97 \\
9 \cdot 77 \\
15 \cdot 39 \\
13 \cdot 30 \\
11 \cdot 61 \\
15 \cdot 78 \\
9 \cdot 83 \\
8 \cdot 01 \\
9 \cdot 52 \\
9 \cdot 32\end{array}$ & $\begin{array}{r}100 \\
160 \\
105 \\
100 \\
98 \\
97 \\
120 \\
118 \\
115 \\
90 \\
160 \\
100 \\
180 \\
103 \\
100 \\
100 \\
190 \\
102 \\
100 \\
100\end{array}$ & $\begin{array}{l}+0.87 \\
+0.92 \\
+0.79 \\
+0.77 \\
+0.76 \\
+0.82 \\
+0.85 \\
+0.90 \\
+0.84 \\
+0.72 \\
+0.88 \\
+0.94 \\
+0.66 \\
+0.78 \\
+0.89 \\
+0.87 \\
+0.94 \\
+0.94 \\
+0.94 \\
+0.93\end{array}$ & $\begin{array}{l}0 \cdot 10 \\
0.11 \\
0 \cdot 13 \\
0 \cdot 10 \\
0.09 \\
0 \cdot 11 \\
0 \cdot 11 \\
0 \cdot 14 \\
0 \cdot 12 \\
0.09 \\
0 \cdot 14 \\
0 \cdot 15 \\
0.09 \\
0 \cdot 19 \\
0.13 \\
0.09 \\
0.15 \\
0.11 \\
0.13 \\
0.10\end{array}$ & $\begin{array}{r}8 \cdot 41 \\
8 \cdot 13 \\
8 \cdot 71 \\
12 \cdot 19 \\
10 \cdot 09 \\
9 \cdot 50 \\
10 \cdot 11 \\
8 \cdot 30 \\
8.93 \\
10 \cdot 05 \\
8 \cdot 81 \\
8 \cdot 18 \\
10.97 \\
11.55 \\
9.07 \\
12 \cdot 69 \\
8 \cdot 98 \\
9 \cdot 33 \\
9 \cdot 05 \\
11 \cdot 05\end{array}$ \\
\hline $\begin{array}{c}\text { Pooled data } \\
\text { Phase A } \\
\text { Phase B }\end{array}$ & +0.91 & $\begin{array}{l}0.57 \\
0.001 \uparrow\end{array}$ & $\begin{array}{r}9 \cdot 89 \\
80 \cdot 70\end{array}$ & $\begin{array}{r}2238 \\
35\end{array}$ & +0.82 & $\begin{array}{l}0 \cdot 12 \\
0.0004 \uparrow\end{array}$ & $\begin{array}{r}9 \cdot 17 \\
25 \cdot 55\end{array}$ \\
\hline
\end{tabular}

* All values of $r$ significant at the $0.001 \%$ level. $†$ Not significantly different from zero.

Values for $a, b$ and $r$ for pooled data (excluding that from the 25-year-old subject) are also presented for both Phases A and B of growth.

Growth of the oocyte and follicle

In order to establish the pattern of oocyte growth in relation to follicle growth, oocyte and follicle diameters were compared using measurements pooled from the nineteen ovaries studied (Text-fig. 1). Oocyte diameter and follicle diameter were found to be positively and linearly correlated until the oocyte reached a mean diameter of $80 \mu \mathrm{m}$ (range 60 to $120 \mu \mathrm{m}$ ) at a follicle diameter of $124 \mu \mathrm{m}$ (growth phase A). Thereafter, the oocyte ceased to grow whilst follicular growth continued (growth phase B). A similar biphasic relationship was found to exist between oocyte nuclear diameter and follicle diameter. The oocyte nucleus reached a maximum diameter of $26 \mu \mathrm{m}$ (range 
22 to $35 \mu \mathrm{m}$ ) at a follicle diameter of $128 \mu \mathrm{m}$ (Table 1). Thus, the oocyte and its nucleus ceased growth at approximately the same stage of follicle development and their diameters were positively and linearly correlated with each other (Text-fig. 2).

The validity of pooling data from each of the different subjects has been investigated in Table 1. The values of $a$ (regression coefficient) and $b$ (intercept) for Phase $\mathrm{A}$ of the relationships between oocyte and follicle diameter and oocyte nuclear diameter and follicle diameter varied between individuals

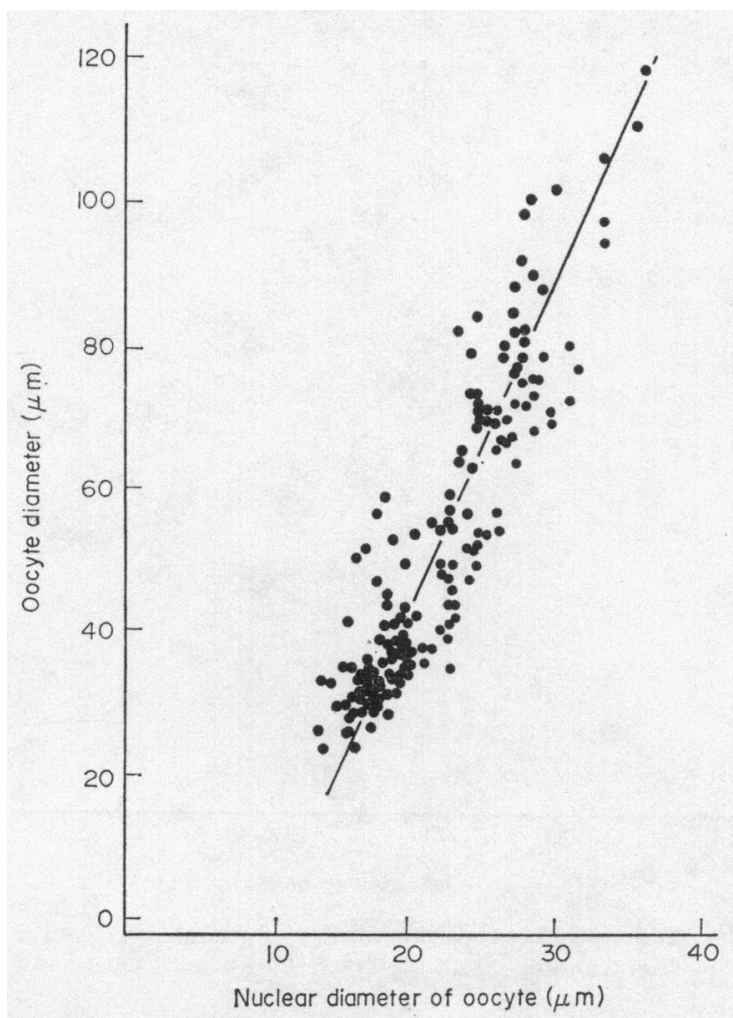

TEXT-FIG. 2. Oocyte diameter $(\mu \mathrm{m})$ and oocyte nuclear diameter $(\mu \mathrm{m})$ in the infant human ovary were positively and linearly correlated $(r=+0.92 ; P<0.001 ; \mathrm{y}=$ $3 \cdot 2 x-43 \cdot 7)$.

but no age trend could be detected. It was not possible to obtain sufficient measurements of follicle and oocyte diameters for Phase B of growth from individual subjects since most of these follicles within each ovary were atretic.

The relationship between follicle diameter and the number of granulosa cells in the widest cross-section of the follicle was curvilinear (Text-fig. 3). In follicles greater than $200 \mu \mathrm{m}$ in diameter, the accumulation of follicular fluid rather than the proliferation of the granulosa cells appeared to determine the follicle size. 


\section{Follicle classification}

The morphological pattern of follicular development in the infant ovary is depicted in Text-fig. 4. In Text-figs 5 and 6, the pooled data from all the ovaries are plotted as histograms to demonstrate the distribution of follicle classes in relation to follicle and oocyte diameter. With the exception of Class $\mathrm{A}$ follicles (Pl. 1, Fig. 1), all of these types of follicles were found in the nineteen ovaries studied.

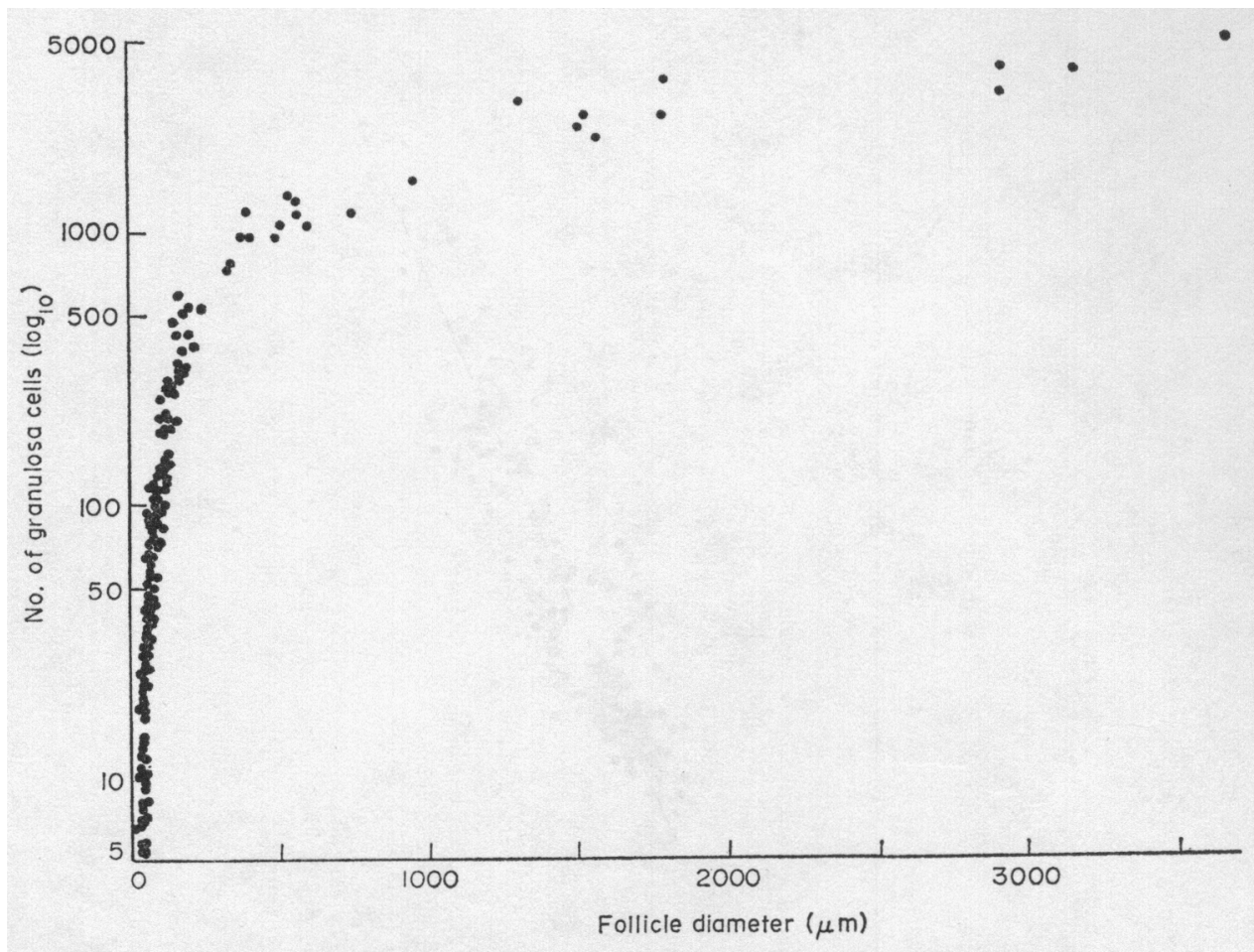

TEXT-FIG. 3. The relationship between the number of granulosa cells in the widest crosssection of the follicle $\left(\log _{10}\right)$ and follicle diameter $(\mu \mathrm{m})$ in the infant human ovary.

There was a considerable overlap in oocyte size between follicle classes. Furthermore, a particular follicle size can encompass a number of morphological classes. Fluid accumulation could commence in follicles with as few as forty granulosa cells in the widest cross-section (Class $D_{1} / D_{2}$ ) and a defined antrum when the number of cells reached 100 (Class E). Similarly, the oocyte might cease growth (Text-fig. 1) at a follicle diameter which included those of both Class D and E morphology (Text-fig. 5). This might include multilaminar follicles with no fluid accumulation.

Based upon these observations, follicular growth in the infant human ovary can be summarized as follows. The preliminary stages of oogenesis are completed by 6 months post partum since oogonia and oocytes in early meiotic prophase (Class A) have disappeared (Pl. 1, Figs la and b). Class B follicles 


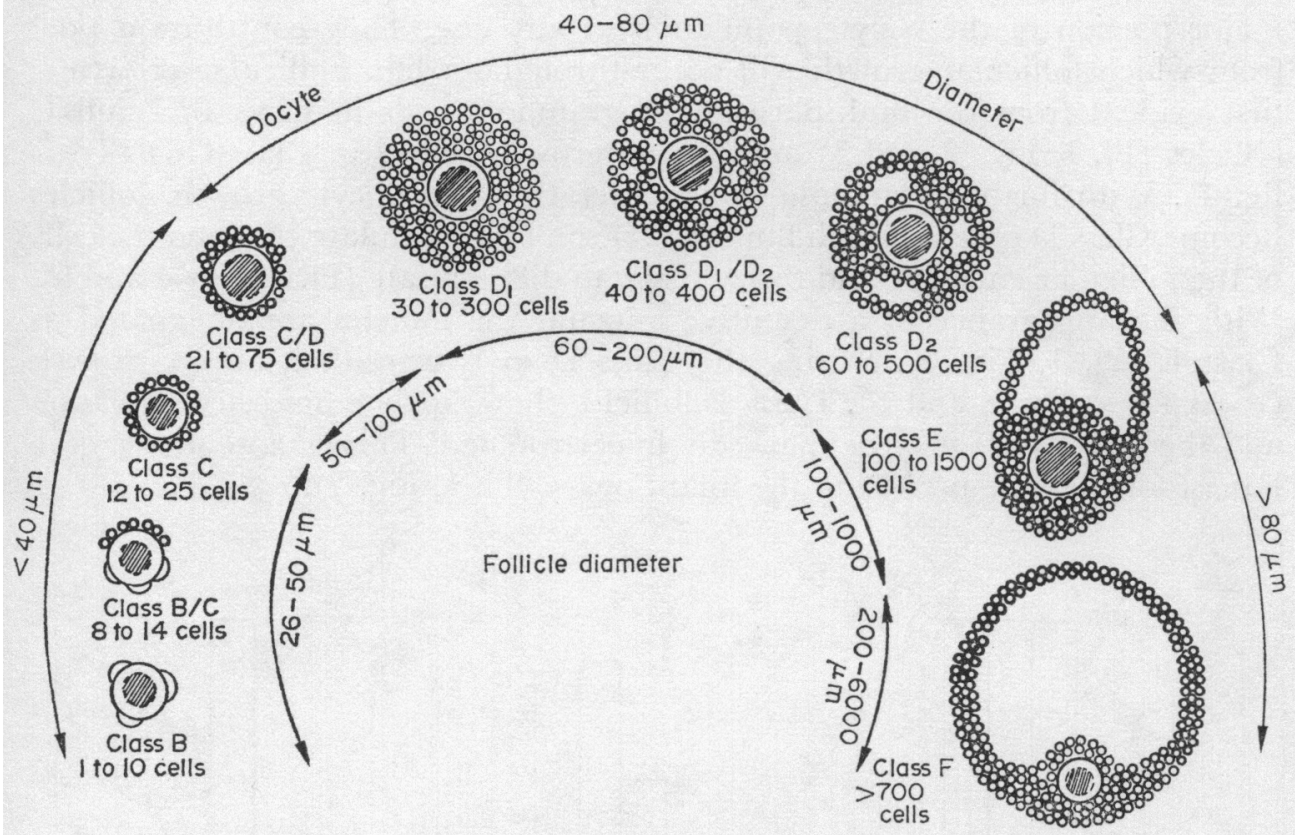

TexT-FIG. 4. Schematic representation of follicular growth in the ovary of infancy and childhood. The classification of follicles was based upon follicle diameter, oocyte diameter, the number of granulosa cells in the widest cross-section and follicular morphology. Class $\mathrm{A}$, which represents oocytes in the early pre-diplotene stages of meiotic prophase (Pl. 1, Figs $1 \mathrm{a}$ and $1 \mathrm{~b}$ ), is not included. Follicular growth occurred first during the transition from Class B to Class G. Oocyte growth commenced during the Class C/D to D transition. Oocyte growth in general ceased during the progression from Class D to Class $\mathrm{E}$ but in exceptional cases occurred as early as Glass $\mathrm{C} / \mathrm{D}$ ('Text-fig. 6 ).

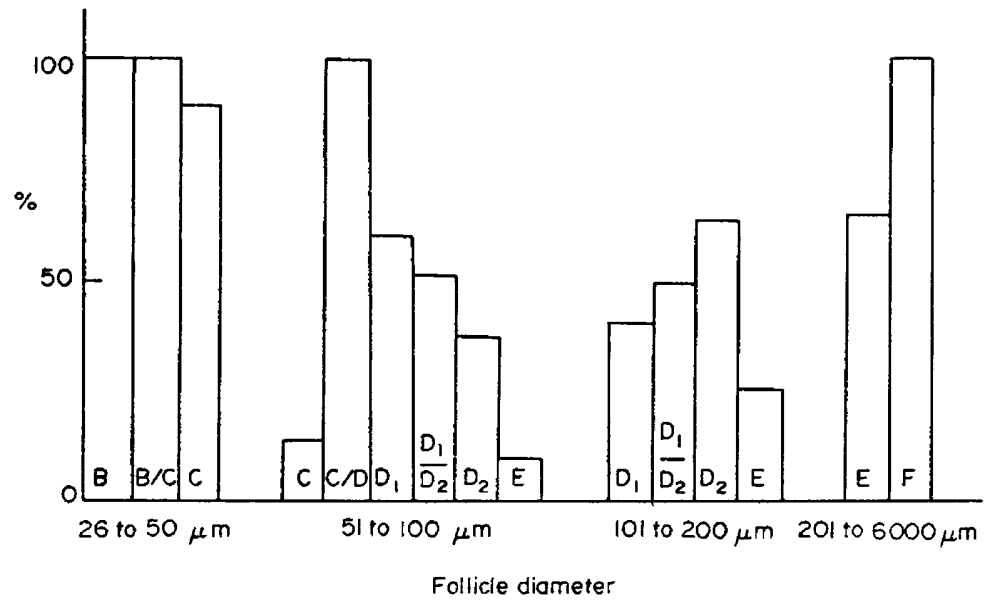

Text-FIG. 5. The distribution of follicle classes in relation to follicle diameter $(\mu \mathrm{m})$ in the infant human ovary. 
(Pl. 1, Fig. 2) are in the resting stage of prophase (diplotene) and form the major portion of the oocyte population at any age. They constitute a pool from which follicular growth will occur throughout life. Follicular growth is first evident from the multiplication of granulosa cells in Class $\mathrm{B} / \mathrm{C}$ and $\mathrm{C}$ follicles (Pl. 1, Figs 2 and 3) and oocyte growth begins in Class C/D (Textfig. 4). With further granulosa cell proliferation and oocyte growth, follicles become Class D type in which fluid may begin to accumulate between the cells of the follicular envelope and thecal tissue to differentiate (PI. 1, Figs 4 and 5). With the appearance of a definitive antrum, the follicles are designated as Class E (Pl. 1, Fig. 6). During the Class D to E transition, oocyte growth ceases (Text-figs 1 and 6 ). Class $\mathrm{F}$ follicles show further fluid accumulation and the thecal cells may be markedly hypertrophied. This class represents the largest follicle type present in the infant ovary (Pl. 1, Fig. 7).

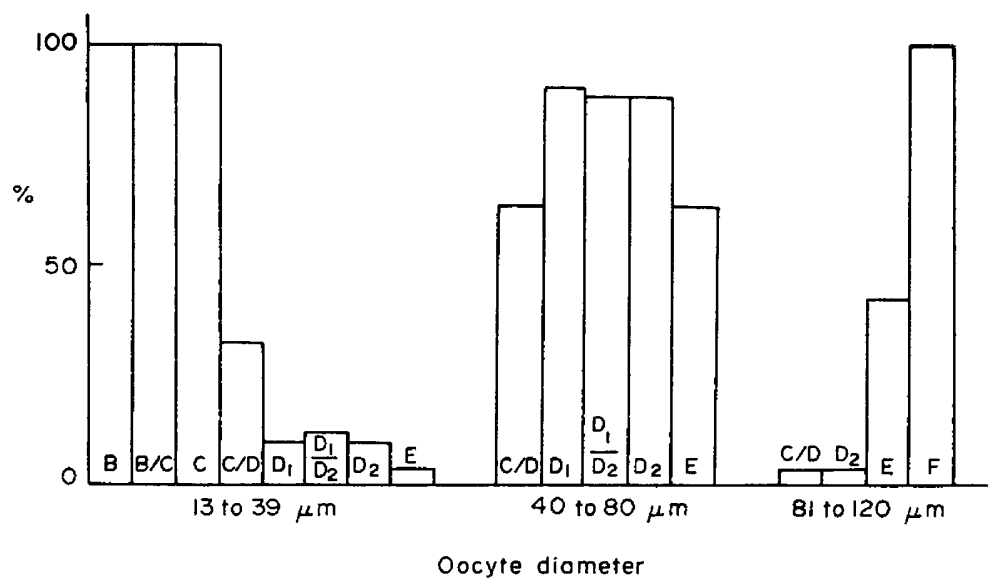

Text-Fig. 6. The distribution of follicle classes in relation to oocyte diameter $(\mu \mathrm{m})$ in the infant human ovary.

\section{DISGUSSION}

The high incidence of antral follicles in the ovaries of newborn girls appears to be unrelated to any pathological state in mother or child. Ahlvin \& Bauer (1957) suggested a relationship between the presence of antral follicles in the newborn ovary and diabetes in the mother, but this was not supported by the more extensive survey of Kraus \& Neubecker (1962). Furthermore, Spivak (1934) and Ober \& Bernstein (1955) found no correlation between hyperplasia and hypertrophy of the newborn uterine endometrium and the presence of antral follicles in the ovary. They concluded that although the morphology of the newborn uterus may reflect maternal steroid levels, the degree of ovarian development was independent of these factors. Advanced stages of follicular growth are also found in the ovaries of other newborn mammals which are born in a comparatively precocious state (Kellas, Van Lennep \& Amoroso, 1958; Perry \& Rowlands, 1962; van Wagenen \& Simpson, 1965). 
As in other mammals (Brambell, 1928; Parkes, 1932; Zuckerman \& Parkes, 1932), the pattern of oocyte growth in relation to follicular growth in the infant human ovary is biphasic (Text-fig. 1) and individual (although not age-dependent) variations may exist in both the regression coefficient, $a$, and the intercept, $b$, for phase $\mathrm{A}$ of growth (Table 1). Similar individual variations also occur in the rhesus monkey and the rat (Green \& Zuckerman, 1947; Mandl \& Zuckerman, 1952). In the human infant, the oocyte reaches a maximum diameter of $80 \mu \mathrm{m}$ (range 60 to $120 \mu \mathrm{m}$ ) at a follicular diameter of $124 \mu \mathrm{m}$. Thereafter, follicular growth continues whilst the rate of oocyte growth approaches zero. The value for $a$ in phase A of growth (0.57) is within the range recorded for other mammals, i.e. 0.14 for the pig and 0.64 for the shrew (see Parkes, 1932; Green \& Zuckerman, 1947). Furthermore, the overall values for both $a$ and $b$ for phase A for the infant ovary did not differ significantly from those obtained for the single adult ovary studied during the course of this work (Table 1) or those obtained by Green \& Zuckerman (1951) for a 6-year-old ovary. The close similarity in many different mammalian species between the maximum diameter achieved by the oocyte at the end of growth phase $\mathrm{A}$ and the corresponding follicle diameter has been noted previously (Parkes, 1932; Brambell, 1956). The possible functional significance of this observation in relation to synthetic activity of the oocyte nucleus has been discussed elsewhere (Moore \& Lintern-Moore, 1974).

No evidence for ovulation was found in any of the 400 ovaries studied. The maximum diameter achieved by the oocyte during infancy (60 to $120 \mu \mathrm{m}$ ) is less than that (120 to $190 \mu \mathrm{m}$ ) reported for freshly ovulated human ova (Pincus \& Saunders, 1937; Hamilton, 1944). Although some of the disparity in size can be accounted for by shrinkage on fixation (Hamilton, 1944; Menkin \& Rock, 1948), it is possible that the fully grown oocyte of infancy does not develop to the preovulatory dimensions found in the adult. Similarly, the maximum diameter of antral follicles encountered routinely in the infant ovary $(5$ to $6 \mathrm{~mm}$ ) is considerably less than the values of 10 to $15 \mathrm{~mm}$ reported for a full-sized adult follicle (Watzka, 1957). Thus, it is concluded that antral follicles in the infant human ovary do not achieve preovulatory size and all of the apparently normal growing follicles seen, in the absence of a resting stage beyond Class B, must, at some stage in development, degenerate. Certainly, all classes of follicles described for the infant ovary were encountered in atretic forms (see also Potter, 1963; Valdes-Dapena, 1967) and the pattern of follicular atresia appears to resemble closely that described for non-ovulatory follicles in the adult Macaca mulatta (Koering, 1969).

The data indicate that follicular growth and degeneration in the human ovary occurs continuously throughout infancy and childhood. It may be pertinent to consider whether a functional association between the gonadalpituitary-hypothalamic axis is also present. Normal prepubertal children have circulating gonadotrophin levels which are considerably lower than those recorded during puberty and adulthood. They are, nevertheless, in excess of those recorded in hypo-pituitary subjects, lower than those of 5- to 10-yearold subjects with gonadal dysgenesis and higher in females than in males. Similarly, although oestradiol-17 $\beta$ levels are also very low, prepubertal subjects 
appear to be more sensitive to low doses of ethinyl oestradiol (as reflected by FSH excretion) than do those who have reached puberty (Kulin, Grumbach \& Kaplan, 1969; Buckler \& Clayton, 1970; Penny, Guyda, Baghdassarian, Johanson \& Blizzard, 1970; Root, Moshang, Bongiovanni \& Eberlein, 1970; Sizoneko, Burr, Kaplan \& Grumbach, 1970; Jenner, Kelch, Kaplan \& Grumbach, 1972; Kelch, Grumbach \& Kaplan, 1972; Lee, Midgley \& Jaffe, 1972). These data suggest that a gonadal-pituitary relationship may exist during the prepubertal period. To support this, Roth, Kelch, Kaplan \& Grumbach (1972) have shown that LH-releasing factor (LH-RF) stimulates the release of similar amounts of FSH in prepubertal, pubertal and adult subjects. By contrast, LH production and release only became significant at puberty. Thus it appears that during infancy and childhood a special, highly sensitive form of the gonadal-pituitary feedback system may be operating. The nature of this system and its relation to the pattern of follicular growth reported here is not known at the present time.

\section{ACKNOWLEDGMENTS}

This study was supported by the NATO Scientific Committee and was carried out in partial fulfilment of EURATOM Contract 120-73-1 BIODK. We wish to thank the pathologists who kindly supplied ovaries used in this study: Dr J. M. Bouton, Alderhey Children's Hospital, Liverpool; Dr H. B. Marsden, Royal Manchester Children's Hospital, Manchester; Dr A. D. Bain, Royal Hospital for Sick Children, Edinburgh; Dr A. E. Claireaux, Hospital for Sick Children, London; Dr G. Molz, Kanton Hospital, Zürich; Dr A. Barzilai, Rambam Government Hospital, Haifa; Dr G. Kohn and Dr J. Chatten, Children's Hospital, Philadelphia; Dr M. J. Barry, Our Lady's Hospital for Sick Children, Dublin.

\section{REFERENCES}

Ahtvin, R. G. \& Bauer, W. C. (1957) Luteinized cysts in ovaries of infants born of diabetic mothers. Am. F. Dis. Child. 93, 107.

BAKer, T. G. (1963) A quantitative and cytological study of germ cells in human ovaries. Proc. $R$. Soc. B, 158, 417.

Boyd, J. D. \& Hamilton, W. J. (1955) The cellular components of the human ovary. In Modern Trends in Obstetrics and Gynaecology, pp. 50-78. Ed. K. Bowis. Butterworths, London.

Brambell, F. W. R. (1928) The development and morphology of the gonads of the mouse. Part III. The growth of the follicles. Proc. R. Soc. B, 103, 258.

Brambell, F. W. R. (1956) Ovarian changes. In Marshall's Physiology of Reproduction, Vol. 1, Part 1, pp. 455-459. Ed. A. S. Parkes. Longmans Green, London.

Buckler, J. M. H. \& Glayton, B. E. (1970) Output of luteinizing hormone in the urine of normal children and those with advanced sexual development. Archs Dis. Childh. 45, 478.

Gurtis, E. M. (1962) Normal ovarian histology in infancy and childhood. Obstet. Gynec., N.Y. 19, 444

Delson, B., Lubin, S. \& Reynolds, S. R. M. (1949) Vascular patterns in the human ovary. Am. F. Obstet. Gynec. 57, 842.

Forbes, T. R. (1942) On the fate of the medullary cords of the human ovary. Contr. Embryol. 30, 9.

Govan, A. D. T. \& MukHERJEe, G. L. (1950) Maternal toxaemia and foetal ovarian activity. $\mathcal{F}$. Obstet. Gynaec. Br. Emp. 57, 525.

GREEN, S. H. \& ZuCKERMAN, S. (1947) A comparison of the growth of the ovum and follicle in normal rhesus monkeys and in monkeys treated with oestrogen and androgens. F. Endocr. 5, 207.

GREen, S. H. \& ZuCRERMAN, S. (1951) Quantitative aspects of the growth of the human ovum and follicle. F. Anat. 85, 373.

Hamilton, W. J. (1944) Phases of maturation and fertilisation in human ova. F. Anat. 78, 1. 
Jenner, M. R., Kelch, R. P., Kaplan, S. L. \& Grumbach, M. M. (1972) Hormonal changes in puberty. IV. Plasma estradiol LH and FSH in prepubertal children, prepubertal females and in precocious puberty, premature thelarche, hypogonadism and in a child with feminizing ovarian tumor. F. clin. Endocr. Metab. 34, 521.

Kelch, R. P., Grumbach, M. M. \& Kaplan, S. L. (1972) Studies on the mechanism of puberty in man. In Gonadotropins, pp. 524-534. Eds. B. B. Saxena, G. G. Beling and H. M. Gandy. Wiley. Interscience, New York.

Kellas, L. M., Van Lennep, E. W. \& Amoroso, E. G. (1958) Ovaries of some foetal and prepubertal giraffe (Giraffa camelopardalis Linnaeus). Nature, Lond. 181, 487.

Koering, M. J. (1969) Cyclic changes in ovarian morphology during the menstrual cycle in Macaca mulatta. Am. F. Anat, 126, 73.

Kraus, F. T. \& NeUbecker, R. D. (1962) Luteinization of the ovarian theca in infants and children. Am. F. clin. Path. 37, 389.

Kulin, H. E., Grumbach, M. M. \& KaPlan, S. L. (1969) Changing sensitivity of the pubertal gonadal hypothalamic feedback mechanism in man. Science, N.Y. 166, 1012.

LEe, P. A., Midgley, A. R. \& JAfFe, R. B. (1972) Regulation of human gonadotropins. VI. Serum follicle stimulating and luteinizing hormone determinations in children. F. clin. Endocr. Metab. 31, 248.

Mandi, A. M. \& Zuckerman, S. (1952) The growth of the oocyte and follicle in the adult rat. $\mathcal{F}$. Endocr. 8, 126.

Menkin, M. F. \& Rock, J. (1948) In vitro fertilisation and cleavage of human ovarian eggs. Am. $\mathcal{F}$. Obstet. Gynec. 55, 440.

MerriLl, J. A. (1963) The morphology of the prepubertal ovary: relationship to the polycystic ovary syndrome. Sth. med. F., Nashville, 56, 225.

MOORE, G. P. M. \& LINTERN-MOORE, S. (1974) A correlation between growth and RNA synthesis in mouse oocyte. F. Reprod. Fert. 39, 163.

Mossman, H. W. \& Duke, K. L. (1973) Comparative Morphology of the Mammalian Ovary, pp. 100-116. University of Wisconsin Press.

Mossman, H. W., Koering, M. J. \& Ferry, D. (1964) Gyclic changes of interstitial gland tissue of the human ovary. Am. F. Anat. 115, 235.

Ober, W. B. \& Bernstein, I. (1955) Observations on the endometrium and ovary in the newborn. Pediatrics, Spring,field, 16, 445.

Parkes, A. S. (1932) The reproductive processes of certain mammals. II. The size of the Graafian follicle at ovulation. Proc. R. Soc. B, 109, 185.

Penny, R., Guyda, H., Baghdassarian, A., Johanson, A. J. \& Butzzard, R. M. (1970) Gorrelation of serum follicular stimulating hormone (FSH) and luteinizing hormone (LH) as measured by radioimmunoassay in disorders of sexual development. F. clin. Invest. 49, 1847.

Perry, J. S. \& Rowlands, I. W. (1962) The ovarian cycle in vertebrates. In The Ovary, Ghap. 5, p. 275. Ed. S. Zuckerman. Academic Press, New York.

Pincus, G. \& SAunders, B. (1937) Unfertilized human tubal ova. Anat. Rec. 69, 163.

Polhemus, M. D. (1953) Ovarian maturation and cyst formation in children. Pediatrics, Springfield, $11,588$.

Porter, E. L. (1963) The ovary in infancy and childhood. In The Ovary, pp. 11-23. Eds. A. G. Grady and D. E. Smith. Int. Acad. Path. Monograph. Saunders, Philadelphia.

Root, A. W., Moshang, T., Bongrovanni, A. M. \& EberLein, W. R. (1970) Concentrations of plasma luteinizing hormone in infants, children and adolescents with normal and abnormal gonadal function. Pediat. Res. 4, 175.

Roth, J. G., Kelch, R. P., Kaplan, S. L. \& Grumbach, M. M. (1972) FSH and LH response to luteinizing-hormone-releasing factor (LRF) in prepubertal and pubertal children, adult males and patients with hypogonadotropic and hypergonadotropic hypogonadism. F. clin. Endocr. Metab. 35, 926.

Savramo, H. (1954) Histology and function of the ovary from the embryonic period to the fertile age. Acta obstet. gynec. scand. 33, Suppl. 2, 1.

SHaw, W. (1925) The fate of the Graafian follicle in the human ovary. F. Obstet. Gynaec. Br. Emp. 3, 679.

Simkins, G. S. (1932) Development of the human ovary from birth to sexual maturity. Am. F. Anat. 51, 465.

Sizoneko, P. G., BurR, I. M., Kaplan, S. L. \& Grumbach, M. M. (1970) Hormonal changes in puberty. II. Correlation of serum luteinizing hormone and follicle stimulating hormone with stages of puberty and bone age in normal girls. Pediat. Res. 4, 36.

SpIvak, M. (1934) Polycystic ovaries in the newborn and early infancy and their relation to the structure of the endometrium. Am. 7. Obstet. Gynec. 27, 157.

Stevens, T. G. (1903) The fate of the ovum and graafian follicle in pre-menstrual life. Obstet. Trans. 14,465 . 
Valdes-Dapena, M. A. (1967) The normal ovary of childhood. Ann. N.Y. Acad. Sci. 142, 597.

van Wagenen, G. \& Simpson, M. F. (1965) Embryology of the Ovary and Testis. Homo sapiens and Macaca mulatta. Yale University Press, New Haven and London.

WatzKa, M. (1957) Weiblich genitalorgane. Das Ovarium. In Handbuch der mikroskopischen Anatomie des Menschen, Vol. 7, pp. 1-178. Eds. W. V. Möllendorf and W. Bargmann. Springer, Berlin.

Winter, G. F. (1962) Follikel-Zählungen und den Eierstöcken gesunder, nicht-schwangerer weiblicher Personen. Zentbl. Gynäk. 47, 1824.

Zugkerman, S. \& Parkes, A. S. (1932) The menstrual cycle of the primates. Part V. The cycle of the baboon. Proc. zool. Soc. Lond. 1932, 139. 